\title{
Gazette
}

\section{APSA Awards Presented at the 1988 Annual Meeting}

\section{DISSERTATION AWARDS}

(Each award includes a cash prize of \$250)

Gabriel A. Almond Award, for the best doctoral dissertation completed and accepted during 1986 or 1987 in the field of comparative politics.

Recipient: David Friedman, Los Angeles, California, "The Misunderstood Miracle: Politics and the Development of a Hybrid Economy in Japan," submitted by the Massachusetts Institute of Technology.

Selection Committee: Barbara Chotiner, University of Alabama; Mark Kesselman, Columbia University, chair; Larry Shrader, Mills College.

\section{Dissertation Chair: Richard J. Samuels}

Citation: David B. Friedman's The Misunderstood Mirocle: Politics and the Development of a Hybrid Economy in Japon is an audacious and creative analysis of Japanese political economy, with sidelong (and penetrating) glances at the United States. Friedman squarely challenges a common explanation of the Japanese "economic miracle" as the product of strong state intervention consolidating control by large industrial firms (zaibatsu) over the japanese economy. In this view, skillful centralized state inter. vention guided the Japanese economy to achieve competitive advantages through the cost-saving advantages accruing to economies of scale. Instead, Friedman suggests, the smallscale industrial sector and its relatively equal relationship to large-scale manufacturing provides the key to Japanese economic success. Moreover, rather than an exploited appendage of the zaibotsu, small firms are autonomous and successful in their own right. Friedman cogently develops an alternative to the strong statezoibotsu interpretation of Japanese political economy, as well as to theoretical arguments that see economic efficiency generally as deriv- ing from a deepening of mass production techniques. He argues that the key to Japanese economic success is the development of a "hybrid economy," which combines large mass industrial enterprise with a dynamic, adaptable. entrepreneurial small producer sector possessing the ability to exploit market niches and high technology. Friedman's interpretation, which is developed through meticulous historical research, a finely grained examination of the machine tool industry, and a case study of small-scale industrial interrelationships in one locality, is a superb critique of the strong state thesis and other current trends in political science. The dissertation makes an important contribution to theories of the state, political economy, and industrial policy.

Friedman examines failed state attempts to centralize the machine tool industry, illustrative of the state's relative weakness and inability to centralize the Japanese economy. He documents that wages, employment levels, and extent of technological development in small firms are not significantly behind (and in some cases are superior to) those in large firms. He suggests that state planning had had little to do with the success of the machine tool industry; his study successfully questions arguments that seek to establish the Japanese case as a bench. mark for democratic government dominance over the economy. By extending the analysis back to the turn of the century he deepens his critique of the conventional Japanese development model and broadens the theoretical significance of his thesis. He illustrates his argument by a superb case study of the machine tool industry, which suggests how high-tech production need not be based in large firms (the production of numerical control [NC] machine tools is highly decentralized in Japan). Moreover, Japanese NC machine tools are produced to facilitate flexible small-batch production, thereby fostering an adaptable, decentralized economy. The dissertation also examines one locality in which cooperation among numerous small producers maximizes the values both of specialized, flexible production and economies of scale. The case study does an excellent job of tinking local-level activity to national policies and outcomes.

The dissertation imaginatively examines inter- 
relationships between political decisions, economic structure, and technical conditions. It squarely challenges the widely accepted interpretation of Japanese economic success as a product of strong state intervention linked to centralized producers churning out massproduced commodities. Friedman also questions the view that sees the American economy as adaptable, flexible, and decentralized. In brief, the Japanese political economy is far better positioned for the shift to post-industrial production.

The Misunderstood Mirocle is an audacious and cogent attempt to challenge established views on Japanese political economy and suggest an alternative interpretation of what has produced the Japanese economic miracle.

William Anderson Award, for the best doctoral dissertation completed and accepted during 1986 or 1987 in the field of intergovernmental relations.

Recipient: No award given this year

Selection Committee: Timothy Conlan. George Mason University; Ann Elder, Illinois State University, chair; Robert D. Thomas, University of Houston.

Edward S. Corwin Award, for the best doctoral dissertation completed and accepted during 1986 or 1987 in the field of public law.

Recipient: Graham Walker, University of Pennsylvania, "The Deep Structure of Contemporary Constitutional Controversy: Morality, Skepticism and Augustine," submitted by the University of Notre Dame.

Selection Committee: Lief $\mathrm{H}$. Carter, University of Georgia; Christine Harrington. New York University, chair; Charles A. Johnson, Texas A\&M University.

\section{Dissertation Chair: Sotirios Barber}

Citation: This dissertation examines the political and philosophical structure of contemporary debates on judicial power and constitutional authority. Graham Walker draws a map of current approaches to the problem of judicial authority in a democratic society and locates a wide range of perspectives, from Robert Bork's writing to contemporary Critical Legal Studies, on it. He argues that the on-going debate between judicial activism and judicial restraint has framed much of the legal and academic discourse on constitutional values. This debate, in Walker's view, is a controversy between moral skepticism and moral realism. Walker demonstrates how these two positions share a realist perspective and concludes that this perspective is unable to adequately address normative issues of judicial power.
Walker argues that a successful normative theory of judicial power must recognize conflicts within everyday moral experiences that are embedded in constitutional values. This means that theory should accommodate conflicting elements of that experience, such as the assumption that there is moral truth and the idea that truth is historically contingent. The debate between judicial restraint and judicial activism fails to embody both elements, and thus there is a tendency within liberal jurisprudence to support skepticism on the one hand or absolutism on the other hand. Neither position, Walker argues, provides a sound basis for normative constitutional theory. Walker turns to Augustine's moral philosophy and proposes a normative constitutional theory that is based on an ontological rather than an epistemological explanation of constitutional values.

Walker's work represents a fresh re-examination of the formal foundations of constitu. tional law. It challenges the terms of conventional scholarship which in Walker's view are limited by the centrality of realist arguments about the nature of judicial power. The dissertation works toward restoring the moral, normative, and visionary enterprise of constitutional theory in political science. This work represents an optimistic alternative and it will encourage debate on normative interpretations of constitutional power.

Harold D. Lasswell Award, for the best doctoral dissertation completed and accepted dur. ing 1986 or 1987 in the field of policy studies (supported by the Policy Studies Organization). Recipient: No award given this year.

Selection Committee: Martin Levin, Brandeis University; Naomi Lynn, Georgia State University, chair; Paul Schulman. Mills College.

Helen Dwight Reid Award, for the best doctoral dissertation completed and accepted during 1986 or 1987 in the field of international relations, law, and politics.

Recipient: Aaron L. Friedberg. Princeton University, "Change, Assessment and Adaptation: Britain and the Experience of Relative Decline, 1895-1905," submitted by Harvard University.

Selection Committee: Whittle Johnston, University of Virginia, chair; Judith Goldstein, Stanford University; Paul Viotti, U.S. Air Force Academy.

\section{Dissertation Chairs: Stanley Hoffmann, Samuel P. Huntington}

Citation: "How do statesmen think about national power and, in particular, how do they seek to measure the power of the nations they 
lead? How do they become aware of changes (especially unfavorable ones) in the relative power of their own country? How do they think about and seek to adapt to such changes? Everything which follows is an attempt to answer these questions." In his learned and penetrating quest to answer the three questions he has posed. Dr. Friedberg advances our understanding of international politics in several significant ways.

He deepens the general awareness of the importance of the "measurement" of power with concrete studies of how this has actually been undertaken. In consequence, he highlights the complexity and indeterminacy of this process, particularly of the self-assessment of relative power by states in decline. He counters the tendencies toward determinism in theories of hegemonic stability and decline, and directs attention to the "mechanisms of perception, analysis and decision" "which intervene between changes in the structure of the international system and specified consequences. He sharpens our appreciation of the degree to which "politics is the realm of chance and choice."

"Within his "heuristic case study" one finds specific studies of how British statesmen sought to gauge changes in four dimensions of power: economic, financial, naval, and land. These assessments, in their turn, were heavily influenced by "simple indicators of national power," e.g., trade statistics, levels of taxation, the Two Power Standard, and reinforcement figures for land forces in India. Such indicators, while essential for the functions of government, also distorted assessment. In conclusion, selfassessments are complex; they change very slowly; in governments where power is dispersed, responses are likely to be uncoordinated.

Dr. Friedberg's study also makes contributions of a more general nature. Through his gifts as an historian, he reminds political scientists of the need to know more about what they think about; through his talents as a political scientist, he reminds historians of the need to think more about what they know. True to Eckstein's admonition, his case study stimulates "the imagination toward discerning important general problems and possible theoretical solutions." His study serves, as well, to build a bridge between the practitioner's need to confront immediate pressures, and the scholar's quest to find a larger meaning in events. His is a work in the tradition of Wolfers and Aron. He uses primary materials exhaustively, and with great empathy for the humanness of the statesmen he studies. Dr. Friedberg's dissertation is a triumph of style: his language is marked by grace and lucidity, his thesis by coherence and proportion.
E. E. Schattschneider Award, for the best doctoral dissertation completed and accepted during 1986 or 1987 in the field of American government.

Recipient: Mark C. Westlye, University of California, Berkeley, "Dynamics of U. S. Senate Elections." submitted by the University of California, Berkeley.

Selection Committee: John F. Bibby, University of Wisconsin-Milwaukee, chair; Murray Havens, Texas Tech University; David Magleby, Brigham Young University.

\section{Dissertation Chair: Raymond E. Wolfinger}

Citation: Though less intensively studied than either presidential or House elections, Senate elections provide unique opportunities to delve into the impact of campaigns on voter choice and to utilize a rich variety of comparisons and controls. Mark C. Westlye in his dissertation, "The Dynamics of U.S. Senate Elections," has taken full advantage of these opportunities and made a major theoretical contribution to the study of American elections. Using an original research design, state level data, and rigorous analysis, he has developed an innovative model of Senate elections, and convincingly demonstrated the impact of campaign intensity on election outcomes.

Westlye's analysis moves beyond constituency based explanations of the differences between House and Senate races which have been the concern of much prior research. His interest is in explaining how Senate elections differ from each other and how different kinds of outcomes can be produced among states of similar size or even within the same state over time. He is seeking explanations for how voters from the same state can elect senators from opposing parties, sometimes with opposing ideologies, both by large margins.

The starting point for Westlye's study is the basic but often overlooked fact that some Senate races are extremely hard fought while others are so low-key as to be almost invisible. Using a series of case studies of both hard fought and low-key campaigns-which involved tracking down extensive amounts of highly $\|-$ lusive state level data he demonstrates that campaign intensity is a key element in determining Senate election outcomes. Campaign intensity is shown to affect the amount of information voters receive about candidates, which in turn influences the impact of incumbency, party based voting, ideology, divisive primaries, and national factors. It is argued, therefore, that the long-term effect of these variables on Senate elections must be analyzed within the context of campaign intensity and the amount of infor. mation voters receive in individual campaigns. 
Because the dynamics of hard fought versus low-key Senate campaigns differ in so many respects, Westlye cautions that analysts are illadvised to search for one factor-such as a national issue, a president's popularity, or the state of the economy-to explain Senate election outcomes in a given year. This is because the same set of conditions is likely to have quite different effects on voters and outcomes depending upon the intensity of the campaign in any particular Senate race.

This dissertation is distinguished by its originality, state level data, theoretical contribution, and analytic rigor. The model of Senate voting behavior that has been developed not only advances the understanding of American electoral behavior, but it also points the way for future researchers.

Leo Strauss Award, for the best doctoral dissertation completed and accepted during 1986 or 1987 in the field of political philosophy.

Recipient: Peter Berkowitz, Deerfield, Illinois, "The Foundations of Nietzsche's Political Philosophy," submitted by Yale University.

Selection Committee: Charles Beitz, Harvard University; Harvey Klehr, Emory University; Harlan Wilson, Oberlin College, chair.

\section{Dissertation Chair: Joseph Hamburger}

Citation: Peter Berkowitz's dissertation, "On the Foundations of Nietzsche's Political Philosophy," is an unusual and original work which inspires us to think about the philosophy of Nietzsche in a genuinely new way.

Berkowitz has produced a close textual exegesis of Nietzsche's writings, focusing on three works: The Birth of Tragedy. The Genealogy of Morals, and, most provocatively. Thus spoke Zarathustra. Setting himself in opposition to the literary deconstructionists, Berkowitz sees Nietzsche as a lover of truth, committed to coherence and reason despite his perspectivist denials, and centrally concerned with the themes of classical political philosophy. Indeed he views Nietzsche as having sided with the classical philosophers against the sophists and politicians, concluding that Nietzsche in the end is profoundly antipolitical. Berkowitz supports this reading with a masterful analysis of the texts, eloquently argued.

Yet the significance of Berkowitz's thesis does not end there. What he has done in this unconventional dissertation is in fact to take Nietzsche's claims seriously and, disdaining extensive commentary on the secondary literature, to hold these claims up to sustained examination. He considers what it actually would mean to live a human life such as Zarathustra's assessing it from Nietzsche's own perspective. His con- clusion is that the consequences (for human will and the quality of life) of Zarathustra's denial of the political, and the notion of eternal return are bleak, even that they are experienced by Zarathustra himself as fraudulent. Thus Berkowitz forces us to re-evaluate Nietzsche's conception of human excellence, and perhaps our own.

Berkowitz's work is deeply thoughtful. written with controlied passion and an extraordinary sense of engagement. It is certain to inspire controversy. Not only does it provide a brilliant interpretation and critique of Nietzsche's central works, but it illuminates many of the great themes of ancient and modern politi. cal philosophy. Its author is certainly a worthy recipient of the Leo Strauss Award.

Leonard D. White Award, for the best doctoral dissertation completed and accepted during 1986 or 1987 in the field of public administration, including broadly related problems of policy formation and administrative theory.

Recipient: Chris C. Demchak, U. S. Military Academy, West Point, "War, Technological Complexity, and the U. S. Army," submitted by the University of California, Berkeley.

Selection Committee: Patricia Ingraham, Syracuse University; Charles Joiner, Temple University, chair; Elaine Sharp, University of Kansas.

\section{Dissertation Chair: Todd R. LaPorte}

Citation: Chris C. Demchak's "War, Technological Complexity and the U.S. Army" completed at the University of California, Berkeley, is a provocative contribution to contemporary administrative theory. It treats a subject of increasingly significant importance demanding serious future analysis in both the public and private sectors in nearly all nations. Her work is further an excellent case study of adaptation by large-scale organizations to required adoption of complex, expensive, and sophisticated postindustrial society technologies.

Numerous propositions are advanced in the study. For one, complex technology increases organization complexity and subsequently increases uncertainty present in organizations. This is partially countered by organization bias for more internal controls to cope with higher knowledge burdens. In her case study of the MI Abrams main battle tank with its computerized subsystems, black box, larger rangefinder and other near-futuristic high-technology devices, Demchak explores various organization responses aimed at retaining internal management control of a machine-oriented military.

She found these responses included management dominance over institutional and techni- 
cal subdivisions in adaptation of organization structure to utllize new complex technologies. The adaptation in turn included greater structural differentiation, increases in number of skill levels within the organization hierarchy, and more subunit interdependence. Additionally, there was more usage of large computers to alleviate design problems and of personal com. puters for operational problems. New, advanced maintenance technologies were substituted (less than successfully) for built-in machine redundancy procedures to allow for back-up of alternative technical subsystems for faltering ones.

Primarily the case study and the theoretical framework in which it is placed present hypotheses for studying administrative variables vis a vis complex technology for organizations generally. She also provides a useful history of armored warfare, of the incidence of technology and weapons systems characteristic of modern military forces, and of the organization structure of the U.S. Army to control changes in technological complexity.

The pragmatic significance of organization handling of technological complexity is dramatically detailed in showing how improvisation in battles is encumbered by the very technology relied upon by the U.S., the U.S.S.R. and many of their allies. This is compounded by the potential, and somewhat inevitable, opera. tional problems generated by the complexity of the technology.

\section{BOOK AND PAPER AWARDS}

Franklin L. Burdette Pi Sigma Alpha Award $(\$ 250)$, for the best paper presented at the 1987 annual meeting.

Recipient: Ronald Rogowski, University of California, Los Angeles, "Changing Exposure to Trade and the Development of Political Cleavages."

Selection Committee: Robert Arseneau, Dartmouth College; Robert Jervis, Columbia University; W. Ofuatey-Kodjoe, Queens College and Graduate Center, CUNY, chair.

Citation: Professor Rogowski proposes an explanation of the development, continuity and change of political cleavages within countries. This explanation is based on a hypothesis which states that increases and decreases in the costs and benefits of international trade should powerfully affect domestic political cleavages in different countries on the basis of differences in their factor endowments. He then shows that this hypothesis conforms with observed patterns of political cleavages in a variety of countries during four periods of global changes in exposure to trade: the sixteenth century, the nineteenth century, the Depression of the 1930s and the post World War II period.

Rogowski's hypothesis is developed from twc ideas. The first idea is the well-known Stolper-Samuelson (1941) Theorem on the costs and benefits of protection and trade liberalization to owners and intensive users of production factors. According to this theorem, protectionist policies tend to benefit owners and intensive users of productive factors in which the country is relatively poorly endowed, and hurts owners and intensive users of factors in which the country is relatively well endowed. Conversely, trade liberalization policies tend to benefit owners and intensive users of productive factors in which the country is relatively well endowed and hurt owners and intensive users of factors in which the country is relatively poorly endowed. Rogowski adds that the effects that the theorem postulates as the result of tariff policy are exactly the same as the effects of exogenous changes in trade such as transportation costs, and international hegemony.

The second idea is Rogowski's assumption about domestic political processes: that beneficiaries of change will try to continue the change, while victims of change will try to halt it; and furthermore, those who are enriched by an increase in wealth will be able to expand their political influence. Based on these assumptions and using a three factor economic model, Rogowski postulates that increased exposure to trade must result in urban-rural conflict in two types of economies, and in class-conflict in two other types of economies. For instance, the model predicts that in capital and land poor economies with relative abundance of labor, increase in trade will generate class conflict, with labor pursuing free trade and expanded political power, while landowners, capitalists and capital intensive manufacturers will unite in support of protection, imperialism and exclusionist politics.

Professor Rogowski's theoretical work is in the best tradition of the cumulative development of theoretical insight supported by empir. ical data. His assumptions are clearly stated. His hypotheses are very carefully developed, and his data is cautiously presented. Substantively, Professor Rogowski's model is an important contribution to contemporary research in domestic and international political economy. It points to the relevance of externally induced changes in the internal politics of different countries, without attempting to discredit some of the usual internal factors that are used to explain internal political cleavages. Finally, Professor Rogowski presents us with several interesting ideas which can be used as points of departure in generating further research in political 
economy, such as the internal politics of impe. rialism, and the effect of global factors on the internal politics of Third World countries.

The American Political Science Association is pleased to honor Professor Ronald Rogowski for this outstanding work and his important contribution to the study of the inter-relationships between international and domestic political economies.

Heinz Eulau Award ( $\$ 500)$, for the best article published in The American Political Science Review during 1987.

Recipients: Kenneth Shepsle, Harvard University and Barry Weingast, Hoover Institution. "The Institutional Foundations of Committee Power."

Selection Committee: Paul Beck, Ohio State University; Ellen Comisso, University of California, San Diego; Russell Hardin, University of Chicago, chair.

Citation: On behalf of a committee that included Paul Beck, Ellen Comisso, and myself, I am pleased to announce the first Heinz Eulau award for the best article published in the American Politicol Science Review for last year. The winners are Kenneth A. Shepsle and Barry R. Weingast for their article, "Institutional Foundations of Committee Power," in the March 1987 issue of the Review. It is pleasing that in this article Shepsle and Weingast have addressed and advanced our understanding of a problem on which Heinz Eulau himself has worked. In the face of tough competition from a large number of outstanding pieces, the selection committee chose this article because it best fulfilled several criteria: originality, advancement of theory, breadth of interest, and lucidity.

Very briefly, Shepsle and Weingast apply one of the most powerful and consistent results in public choice theory to the analysis of the institutional structure of Congress. The simple result they use is sometimes called the chaos theorem, that, in multidimensional choice arenas, no alternative is unbeatable. It should follow therefore that aimost no congressional committee bill could be safe from amendments that would make it inferior to the status quo in the view of the committee members. Committees, however, get the last word when legislation goes to conference committee to work out House and Senate differences. In confer. ence, they have an ex post veto that guarantees that they do no worse than the status quo.

The conventional understanding of the power of congressional committees has been that it results from the norms of reciprocity and deference. Shepsle and Weingast urge that this is more a description than an explanation. They therefore look for structural explanations that fit observed results. They conclude that deference to committees and reciprocity between legislators during the amendment process is backed by committee control over final outcomes and is not the source of that control. The fruitfulness of the work of Shepsle and We. ingast is suggested by follow-up commentary that their article has already provoked. It seems likely that they have changed the terms of discussion for this problem.

This article is a contribution to an emerging third major area of work in public choice. The two traditional and dominant areas of such work have been in collective choice in the tradition of Kenneth Arrow and Duncan Black, and in collective action in the tradition of Anthony Downs and Mancur Olson. The area to which Shepsle and Weingast have been among the leading contributors is the analysis of institutions as these are determined by rational incentives faced by those who affect the institutional structures and actions. Shepsle and Weingast have especially led the way in the public choice analysis of legislatures, as in their Eulau Award article, with special reference to the U.S. Congress. Not least among their accomplishments is that they write with such lucidity that virtually everyone in the discipline can appreciate and understand their findings.

Ralph J. Bunche Award (\$500), for the best scholarly work in political science published in 1986 or 1987 which explores the phenomenon of ethnic and cultural pluralism.

Recipients: Earl Black, University of South Carolina, and Merle Black, University of North Carolina, Politics and Society in the South. Harvard University Press.

Selection Committee: Robert Holmes, Atlanta University, chair; Rita Mae Kelly, Arizona State University; Belden Paulson, University of Wisconsin-Milwaukee.

Citation: Comprehensive in its scope, sophisticated and rigorous in its analysis and insightful in its conclusions, Politics and Society in the South is a worthy successor to $V$. O. Key's Southern Politics as the best book on politics in the south. Black and Black provide a thorough treatment of the political, psychological-economic-racial issues which contributed to the unique nature of politics in the old confederacy. Starting with the major demographic trends caused by rapid industrialization of the region, the authors examine the Southern "social order" in its various manifestations, including its ideological elements and the transformation/evaluation of race relations. The history of numerous racially discriminatory election laws used by Southern politicians are described along with the more recent 
political mobilization and activity of the new Black electorate. Finally the two Professors analyze how the conservatism of the White Southern electorate on racial and other issues combined with the Democratic controlled Congress in the 1960 and 1970, backing of civil rights legislation beneficial to Blacks has contributed to a shift to the Republican party, particularly in Presidential elections and statewide races for Senator and Governor.

Black and Black conjecture that the divergent economic priorities of Southern Blacks and Whites and the dominance of White voter registration continue to influence the nature of electoral politics in the region. Class, race and conservatism will be constants, however, a major change already evident is the decline of White leadership from the Black Belt areas along with more blatant forms of Southern racism. A new urban based middle class political elite has risen as well as growing support of the Republican party among the college educated middle class and the White masses. A major prediction is for a sharpening of the struggle between the moderate and conservative middle class with their different agendas, priorities and styles. Both the Democrats and Republicans will support policies designed to maintain a favorable economic development climate such as low taxes as well as back programs beneficial to the middle class while reducing spending for social welfare programs. Recent events under the "New Federalism" have borne out their predictions. Future elections, it is suggested, will focus less on BlackWhite differences, but will be characterized by open political conflict involving differences within the new White urban middle class elite. In summation, the authors write, "Southern politics can be expected to perpetuate much of the past even as a different future beckons."

This cogent and well written study provides a new standard against which future texts on Southern politics will be measured. It is a tour de force and is most deserving of the honor as "the best scholarly work in political science which explores the phenomenon of ethnic and cultural pluralism."

Gladys M. Kammerer Award $(\$ 1,000)$, for the best political science publication in 1987 in the field of U. S. national policy.

Recipient: Dennis F. Thompson, Harvard University, Political Ethics and Public Office. Harvard University Press.

Selection Committee: David Baldwin, Columbia University; Charles Gilbert, Swarthmore College, chair; Linda Williams, Joint Center for Political Studies.
Citation: Of the numerous excellent books nominated, this book stands out for the significance of its subject as well as for the successful execution of its author's undertaking. That undertaking was to define and apply a "political ethics"-an approach to the ethical evaluation of political action that is both informed by the traditions of ethical philosophy and sensitive to the particular difficulties of political conduct. Political Ethics argues on the one hand that ethical principles properly apply to most political action, but also that political action tends especially to implicate conflicts of ethical principles, which therefore often don't apply directly. Thus political ethics, says Thompson, has much less to do with particular rules or general theories than with a method of judging public conduct. The method he employs attends both to "middle-level" ethical principles that are generally accessible and to the circumstances of political action, considering each critically in the light of the other.

Political Ethics and Public Office applies this style of analysis to a series of characteristic ethical issues in public life, with numerous examples from the field of U.S. national policy. While the analysis refines our understanding of these issues in general, the examples help to make clear how it might apply in detail to specific actions. Crucially, the political ethics Thompson proposes isn't for ethicists primarily; it is for citizens, officeholders, and intermediar. ies (who may be both). It both depends upon and can help enhance the institutions and understandings of political democracy.

One needn't agree with particular conclusions of Thompson's analysis to applaud its contribution in the large. Four accomplishments of Political Ethics and Public Office are especially notable. (1) It usefully identifies and sophisticates our understanding of a set of characteristic ethical issues in public policy and conduct. (2) In doing so, it demonstrates the feasibility and the validity in principle of the analytic method it propounds for a political ethic. (3) In particular. the analysis focuses on the personal responsibility of public officeholders, both elective and appointive. It indicates practical ways of em. phasizing and strengthening personal responsibility without neglecting either organizational context or collective purpose. (4) Finally, all of the foregoing accomplishments stand potentially as contributions to democratic theory and practice. The analytic method of political ethics holds promise for improving public discussion toward operative agreement on criteria for judging the conduct of public servants, including at least provisional conceptions of the public in. terest. And its emphasis on publicity and accountability is a challenge to improve American institutions in these respects. 
Victoria Schuck Award $(\$ 500)$, for the best book published in 1986 or 1987 on women and politics.

Recipients: Rebecca E. Klatch, University of California, Santa Cruz, Women of the New Right. Temple University Press; and Jane Mansbridge, Northwestern University, Why We Lost the ERA, University of Chicago Press.

Selection Committee: Susan f. Carroll, Eagleton Institute of Politics, Rutgers University; Jean Bethke Elshtain, Vanderbilt University, chair; Norma Noonan, Augsburg College.

Citations: 1988 marks the first year for the presentation of the Victoria Schuck Award for the best book published on women and politics. The Committee reviewed books which appeared in 1986 and 1987. All entries were sub. mitted by publishers who had been issued in vitations to nominate books from Catherine $E$. Rudder, Executive Director of the Association. The Committee received over two dozen books and divided them into the broad categories of political theory, comparative politics. and American politics. Each book was read and reviewed by at least one committee member. A short list of strong entries was required reading for each member. The committee's deliberations included fruitful discussions concerning the interdisciplinary nature of current women's studies scholarship. We learned that many political scientists find it vital to their own enterprise to reach outside its confines in order to explore social history, anthropology, sociology, psychology and literature. Given the scope and variety of the books submitted for our consideration, it is perhaps not surprising that the committee decided the award should be shared by two exemplary texts.

Rebecca E. Klatch, a sociologist at the University of California, Santa Cruz, turned her critical attention to Women of the New Right (Temple University Press, 1987). The committee was impressed with Klatch's even-handedness and her sympathetic efforts at understanding, and conveying sensitively, perspectives at odds with her own. Her method of non-argumentative participant-observation allowed Klatch to gain a wide-ranging appreciation of "the central symbols and beliefs valued by groups of people who share a political ideology." At the same time, she never lost sight of the fact that generalizations to the entire universe of women who identify with the "new right" were not in order given the scope of her own field research and samples. Any and all such universal conclusions should be approached with appropriate caution by those who research subjects are thinking, acting human beings, she cautions.
Klatch illumines the many "ideological strains" that separate "social and lassez-faire conservatism." We learn that the New Right is no monolith but a shifting and varied group of individuals, affiliations, and organizations. No tidy definition of "conservative" or "rightwing" captures the diversity of this complex social and political scene. Instead, the scholar's definitions must be rooted in "the historical reality of the time." Abstract or ideological constructions obfuscate what is going on, particularly with a topic as loaded as "new right" women. The activist women Klatch interviewed were "self-identified" as well as "labelled by others as conservative." Yet Klatch found that many lassez-faire conservative women, despite popular misperception. do not consider feminism a threat. "Rather. lassez-faire women actually support part of the feminist agenda." Right-wing women are as diverse in their views and activities as feminists. Klatch's carefully formulated but provocative conclusion is that the world-views and actions of the "social conservative" and the "laissezfaire conservative" serve, ironically, to cancel one another out, with the former urging social responsibility, limits to individualism and selfexpression, and the latter preaching self-interest and a libertarian approach to personal behavior. Although Women of the New Right is the work of a junior scholar, Klatch's appreciation of complexity, her clarity concerning the strengths and limitations of her own approach, and her insistence on respecting and listening to those "different from ourselves," display the developed traits of a mature researcher.

Why We Lost the ERA is a controversial book by a respected, senior scholar on a topic that generates enormous political heat but precious little scholarly light. Jane Mansbridge's study, published by the University of Chicago Press in 1986, is a rare and perspicuous combination of engaged yet dispassionate and skeptical scholarship. Her book stands out in its refusal to indulge in easy targeting of culprits and celebration of heroines. As with the historic struggle over women's suffrage, supporters of the ERA tended to exaggerate its beneficial effects and opponents overdrew its baneful possibilities. Mansbridge sees a deep irony in all this because "the ERA would have had much less substantive effect than either proponents or opponents claimed." For example, because it applied only to government and not to private businesses and corporations, "it would have had no noticeable effect, at least in the short run, on the gap between men's and women's wages." As well. The Supreme Court during the 1970s has used the 14th amendment to "declare unconstitutional almost all the laws and practices that Congress had intended to 
make unconstitutional when it passed the ERA in 1972." So why the enormous commitment of feminist and liberal time and energy to a decade long, eventually losing fight?

Mansbridge believes that the "defeat was a major setback for equality between men and women." Although the direct effects might have been negligible, in the long run passage would likely have catalyzed a rethinking of received interpretations of existing laws as well as the enactment of new laws of benefit to women. Attuned to the contested meanings of "equality," Mansbridge homes in on Illinois as a case study, a microcosm of ERA politics, although she recognizes that ratification struggles varied from state to state. Her chapters on the pitfalls of the amending process as an instrument of social change, on the ill-suitedness of the ERA to make a major alterations in the economic circumstances of women, and on the ERA and the War Powers Clauses are pithy and provocative, useful for teachers and students in constitutional law, American politics, and political theory.

One of her most debated, and debatable. claims is that ERA proponents need not, as most did, endorse the proposition that passage would have transformed gender into a prohibited rather than a merely suspect category in constitutional adjudication. Hence the insistence of the National Organization for Women that the ERA "would require the military to send women draftees into combat on the same basis as men." Mansbridge concludes that ideological commitment to a notion of what "full equality" between the sexes required swamped more prudential, and probably realistic, assessments of political and social change. She wonders: is equality compatible with "exceptions" and finds that ERA activists, for the most part, said "no." Their absolutist posture, in turn, helped to generate strong countermobilization by women for whom the image of their daughters marching forth to war was anathema. Once the ERA "lost its innocence," Mansbridge surmises, it was doomed. In her concluding chapter, she elaborates her scholarly and political conviction that the ERA should not now be resuscitated as the "institutions of adversary democracy," aroused to a fever pitch at the height of the ratification struggle, would once again guarantee polarization around passage and inhibit the "serious national debate" about "the amendment and its implications" we require but seem, for the time being, prepared to evade. Why We Lost the ERA is essential reading for all students of American politics.

Woodrow Wilson Foundation Award $(\$ 2,000)$. for the best book published in the United
States during 1987 on government, politics, or international affairs.

Recipient: Robert Gilpin, Princeton University, The Political Economy of International Relations. Princeton University Press.

Selection Committee: Peter Katzenstein, Cornell University; James Lengle, Georgetown University; Ezra Suleiman, Princeton University, chair.

Citation: Robert Gilpin's, The Political Economy of International Relations, succeeds in synthesizing developments in a field of knowledge that Gilpin's scholarship has greatly helped to revive in this country. The book's central concern is the impact of international economics on international political institutions. It seeks to bridge the gap between disciplines and in so doing sets an agenda for the students of international relations.

The Political Economy of International Relations is a magisterial work. noteworthy for its broad scope. The work is sensitive to theory, policy and ideology. It covers such important topics as money, trade, foreign investment, economic development and international finance. It assesses the impact of economic activity on the structure of the international political system.

One of the chief merits of Gilpin's book is that it is a highly sophisticated work that nonetheless remains accessible to undergraduates, graduate students, and scholars. It is an ambi. tious work and it delivers on its promise to bring together between two covers an entire field of scholarship. At a time when so much change is occurring in the world economy and in relations among the major powers, Gilpin's work, through its sensitivity to the problems of change, helps us to place in perspective a, bewildering array of economic and political transformations. The central aim of this broad and thoughtful work is to elucidate how the transformation of the global economic order interacts with the realities of the international state system.

\section{CAREER AWARDS}

Carey McWilliams Award (\$500), presented each year to honor a major journalistic contribution to our understanding of politics.

Recipients: Jeffrey $\mathrm{H}$. Birnbaum and Alan S. Murray, Wall Street journal.

Selection Committee: Bernard C. Cohen, University of Wisconsin-Madison; Doris Graber. University of Illinois at Chicago; Nelson W. Polsby, University of California, Berkeley, chair.

Citation: Journalists are capable of assisting the work of political scientists in many ways. One of 
the most important ways they can help us to understand our political world is by using their primary access to political events and actors to make available to us thorough reconstructions of the circumstances surrounding major decisions of our time. A particularly careful such reconstruction has been provided by Jeffrey $H$. Birnbaum and Alan S. Murray of The Wall Street journal in their book Showdown at Guccl Gulch: Lowmokers, Lobbyists, and the Unlikely Triumph of Tox Reform (New York: Random House, 1987). This book, which arises out of their painstaking daily reporting on the tax reform bill of 1986, describes step by step and with a wealth of meaningful detail the significant events and episodes leading to an extremely important cluster of changes in the law of the land.

That Birnbaum and Murray were able to go so thoroughly into these events and present them fairly and fully is a hallmark of the work of the Journal's Washington bureau under the leadership of Albert R. Hunt, his predecessor Norman Miller, and that great Journol pioneer of Congressional studies, Alan L. Otten. In awarding Mr. Birnbaum and Mr. Murray the Carey McWilliams Prize for 1988 we mean also to pay tribute to the intellectual excellence of the journal's tradition of Capitol Hill coverage.

This was unanimously agreed to by all three members of the committee.

Hubert H. Humphrey Award (\$500), presented each year in recognition of notable public service by a political scientist.

Recipient: Jeane J. Kirkpatrick, Georgetown University.

Selection Committee: Joyce Kallgren, Univer. sity of California, Davis; John Ryan, Indiana University, chair: John G. Stewart, Tennessee Valley Authority.

Citation: The American Political Science Association's Hubert H. Humphrey Award is presented each year in recognition of notable public service by a political scientist. The Award for 1988 is presented to Dr. Jeane Jordan Kirkpatrick, who served from 1981 to 1985 as the Permanent Representative of the United States to the United Nations and now serves as the Thomas and Dorothy Leavey University Professor of the Foundations of American Freedom at Georgetown University and as Senior Fellow and Counselor to the President for Foreign Policy Studies at the American Enterprise Institute.

Like all of the previous honorees, Jeane Kirkpatrick was well known, widely read, and greatly admired as a scholar and teacher before she entered public life. Like most of them, she returned to scholarship and teaching after retiring from office. And like several of them, she was a longtime political associate and personal friend of Hubert Humphrey.

Jeane Kirkpatrick received her baccalaureate degree from Barnard in 1948, and spent a year as a French Government Fellow at the Institute of Political Studies at the University of Paris. She then married a distinguished political scientist, Dr. Evron M. Kirkpatrick, who was Executive Director of this Association from 1954 to 1981. For a decade they raised a family of three sons while she continued her development as a political scientist. In 1961 she resumed her academic career as an Assistant Professor at Trinity College in Washington, D.C. She organized her family and teaching responsibilities to permit completion of her Ph.D. at Columbia University in 1967. In that same year she moved to Georgetown University where she has played a major role.

By the late 1950 s Dr. Kirkpatrick was widely regarded as one of the most productive and original scholars of her generation in the fields of political theory, political psychology, comparative government, and American parties and politics. Her work, then and now, was premised on her efforts to apply the theoretical framework of her great friend, Harold D. Lass. well, to the analysis of mass and elite opinion and behavior in a variety of political cultures. Her first book, Leoder and Vonguard in Moss Society (197|), analyzed survey data on the beliefs and behavior of the Peronistas in Argentina. Her second book, Political Woman (1974) was one of the first studies of the changing role of women in American politics, and-perhaps with a prescience she could not have recog. nized at the time - it focused on women who were successful in politics, using as its main data in-depth interviews with women who had overcome the cultural and political barriers of the time to achieve positions of power and influence in state legislatures.

Her third book. The New Presidential Elite (1976) remains to this day a pioneering and widely-cited study of the attitudes and roles of delegates to the 1972 national conventions of both parties.

In 1977 she added to her Georgetown duties a position as a Resident Scholar at the American Enterprise Institute, and in 1978 she pub. lished her fourth book, Dismantling the Porties: Reflections on Party Reform and Party Decomposition, one of the first studies that analyzed the cause and consequences of the decline of American political parties.

Thus in seven years Jeane Kirkpatrick published four books and a number of articles widely read and much admired by her fellow political scientists. Then in 1979 she published in 
Commentory an article on "Dictatorships and Double Standards," which was soon read far more widely and debated far more heatedly than anything she had published before. It also caused Ronald Reagan first to seek her advice in his 1980 campaign for the presidency and then in 1981 to name her as United States Ambassador to the United Nations.

We cannot say, however, that the 1979 article moved her out of the academy onto the political battlefield, for she had already been active in Democratic party politics for well over a decade. In 1968 and 1972 she and her husband served as Hubert Humphrey's main polling analysts. In 1973 she and Humphrey co-chaired the Democratic National Committee's Commission on Vice-Presidential Selection. From 1974 to 1976 she served as a member of the Democratic party's Winograd Commission for making yet more revisions in the rules for selecting national convention delegates. And in 1976 she served as Senator Henry M. Jackson's representative to the Democratic party's platform committee.

In sum, well before Jeane Kirkpatrick went to the UN, her teaching and research made her well known to political scientists, and her work for Humphrey and the Winograd Commission made her well known to Democrats. From 1981 to 1985 she served as the first-and, as of now, the only-woman to represent the United States at the UN, and in those years she became, as she is today, well known all over the world.

The committee is well aware that, like anyone who plays the role of political advocate with energy and eloquence, Jeane Kirkpatrick is controversial. Many people admire her for understanding that the UN is a political system and for using it unapologetically to defend America's democratic values and performance before the representatives of nations who neither share the values nor approve the performance. Other people have criticized her for precisely the same reasons and for the decision to change political party allegiance. We note parenthetically that Senator Daniel Patrick Moynihan, the only other winner of this award to hold the UN post, received strikingly similar praise and denunciation for using the position much as Ambassador Kirkpatrick used it.

Jeane Kirkpatrick has already received many high honors for her public service, including the Humanitarian Award of B'nai B'rith, the Harry
S. Truman Good Neighbor Award, and, in 1985, our nation's Medal of Freedom. In presenting to her the 1988 Hubert $\mathrm{H}$. Humphrey Award, named as it is for her longtime friend and political associate, and presented as it is by her fellow political scientists, we hope she will know that she is one prophet who is not without honor in what we believe will always be her intellectual and professional home.

John Gaus Lecture $(\$ 1,500)$, presented each year to honor a scholar who best embodies the joint tradition of political science and public administration and, more generally, to recognize achievement and encourage scholarship in public administration.

Recipient: James W. Fesler, Professor Emeritus, Yale University (Fesler delivered the Gaus Lecture, "The State and its Study: The Whole and the Parts," at 5:30 p.m., -riday, Septem. ber 2 in the East Ballroom, Washington Hilton Hotel).

Selection Committee: Patricia Florestano, University of Maryland; Herbert Kaufman, Boston College: Martin Landau, University of California, Berkeley, chair.

Citation: James W. Fesler's career symbolizes the spirit and substance of the John M. Gaus Award. A thoughtful and productive scholar, he has brought to public administration the breadth and vision of political science, and to political science the special insights of a field concerned with the place of public bureaucracies in the modern state. His investigations and analyses have informed and guided decades of students of politics, government, and public administration, and will continue to do so for many years to come. His pioneering work on the tension between area and function in public organization broke new ground and his commentaries on centralization and decentralization, both political and administrative, cast fresh light on persistent fundamental problems. His work on the relation between political leaders and higher civil servants has been singularly insightful, and his examinations of the goals and methodology of political science and public administration have left us in his debt. It is, therefore, with the greatest pleasure that the Association confers on this gracious colleague, whose work has consistently been marked by an acute intelligence and clarity of thought, the John Gaus Award. 